\title{
Pengaruh Efektivitas Komite Audit, Efektivitas Internal Audit dan Kualitas Audit terhadap Pengungkapan Sukarela
}

\author{
Hanny Purnomo ${ }^{1}$ \\ Fakultas Ekonomi dan Bisnis \\ Universitas Airlangga, Indonesia \\ Email: hannyprnm@gmail.com
}

\author{
Yustrida Bernawati ${ }^{2}$ \\ Fakultas Ekonomi dan Bisnis \\ Universitas Airlangga, Indonesia
}

\begin{abstract}
ABSTRAK
Tujuan penelitian ini untuk membuktikan secara empiris pengaruh efektivitas komite audit, efektivitas internal audit dan kualitas audit terhadap pengungkapan sukarela pada perusahaan yang terdaftar di Bursa Efek Indonesia periode 20162018. Sampel dipilih dengan menggunakan teknik purposive sampling sehingga diperoleh jumlah sampel sebanyak 100 perusahaan, hipotesisi diuji menggunakan regresi linier berganda. Hasil penelitian ini menunjukkan ba hw a efek tivitas komite audit, efektivitas internal audit dan kualitas audit berpengaruh terhadap pengungkapan sukarela perusahaan.
\end{abstract}

Kata Kunci: Efektivitas Komite Audit; Internal Audit; Kualitas Audit; Pengungkapan Suakrela.

\section{Effect of the Effectiveness of the Audit Committee, Internal Audit and Audit Quality on Voluntary Disclosure}

\section{ABSTRACT}

The purpose of this study is to prove the truth, internal audit, internal audit, and audit quality on voluntary disclosures in companies listed on the Indonesia Stock Exchange for the period of 2016-2018. The sample was selected using a purposive sampling technique to obtain a sample of 100 companies, the hypothesis was taken using multiple linear regression. The results of this study prove the importance of audit audits, internal audits, and audit quality applied to company voluntary disclosures.

Keywords: Effectiveness of Audit Committee; Internal Audit; Audit Quality; Voluntary Disclosure.

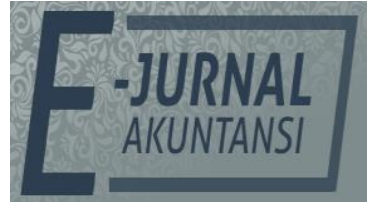

E-JA

e-Jurnal Akuntansi e-ISSN 2302-8556

Vol. 30 No. 4

Denpasar, April 2020

Hal. 861-873

Artikel Masuk: 6 Desember 2019

Tanggal Diterima: 28 Maret 2020 


\section{PENDAHULUAN}

Laporan keuangan merupakan sebuah sarana utama untuk mengkomunikasikan informasi keuangan perusahaan kepada pihak-pihak di luar perusahaan (Kieso et. al., 2019), sehingga laporan keuangan harus memiliki informasi yang bebas dari rekayasa serta mengungkapkan informasi yang sesuai fakta. Adanya krisis global membuat tidak sedikit perusahaan multinasional dan perusahaan dalam negeri serta jasa akuntan publik mulai diragukan dan dipertimbangkan kredibilitasnya. Keraguan dan pertimbangan tersebut muncul dikarenakan banyak kasus manipulasi pada laporan keuangan perusahaan yang disebabkan adanya praktek bad management. Praktek bad management akan memberikan dampak besar bagi perusahaan, akibat menurunnya kepercayaan pihak eksternal akan pengelolan perusahaan (Berger \& DeYoung, 1997).

Adanya krisis global membuat tidak sedikit perusahaan multinasional dan perusahaan dalam negeri serta jasa akuntan publik mulai diragukan dan dipertimbangkan kredibilitasnya. Keraguan dan pertimbangan tersebut muncul dikarenakan banyak adanya kasus manipulasi pada laporan keuangan perusahaan. Kecurangan tersebut disebabkan adanya praktek bad management dalam perusahaan untuk memenuhi kemakmuran manajemen perusahaan. Praktek bad management akan memberikan dampak besar bagi perusahaan, akibat menurunnya kepercayaan pihak eksternal akan pengelolan perusahaan (Berger \& DeYoung, 1997).

Salah satu praktek bad management yang menggemparkan dunia dilakukan oleh perusahaan energi di Amerika Serikat yaitu Enron yang menyembunyikan kerugian besar dari anak perusahaannya. Di Indonesia, manajemen dari PT. Garuda Indonesia Tbk. Pada tahun 2018 PT. Garuda Indonesia Tbk. mengakui transaksi atas kerjasama dengan Mahata Aero Teknologi sebagai pendapatan meskipun belum mendapatkan pembayaran atas kerjasama tersebut hingga akhir tahun 2018. Pengakuan pendapatan tersebut berpengaruh terhadap kinerja laba pada tahun 2018 dengan jumlah $\$ 809$ ribu yang jauh berbeda dari tahun 2017 yang mengalami kerugian sejumlah $\$ 216,58$ (Ulf \& Agi, 2019).

Menurut teori agensi yang dikemukakan oleh (Jensen \& Meckling, 1976), konflik agensi yang terjadi antara principal dan agent disebabkan karena tidak adanya keterbukaan informasi dari agent selaku pengelola perusahaan kepada principal selaku pemilik perusahaan. Selaku pengelola dan lebih mengerti kondisi perusahaan, agent mempunyai informasi yang lebih luas dibandingkan dengan principal. Sehingga untuk meminimalisir kesenjangan informasi, perusahaan perlu mengupayakan untuk melakukan perluasan penyampaian informasi kepada publik dalam laporan keuangan tahunan.

Sebuah upaya pengawasan terhadap perilaku agent diperlukan untuk meminimalisir konflik agensi terutama dalam proses pelaporan keuangan perusahaan (Jensen \& Meckling, 1976). Sebuah mekanisme pemantauan inter nal serta eksternal pun dibutuhkan untuk memastikan pengungkapan yang memadai pada laporan keuangan (Kamolsakulchai, 2015). Oleh karena itu, beberapa langkah yang harus dilakukan untuk memperkuat kualitas tata kelola perusahaan termasuk efektivitas komite audit, audit internal dan praktik audit eksternal (Yassin \& Nelson, 2012). Internal audit berfungsi untuk mengawasi 
manajemen bersama dengan komite audit dan juga memiliki keterlibatan dalam proses pelaporan keuangan dan berkontribusi aktif untuk menciptakan praktik corporate governance yang lebih efektif (Salierno, 2007). Selain itu kualitas audit yang tinggi dari suatu perusahaan maka akan menghasilkan laporan keuangan yang dapat dipercaya sebagai dasar pengambilan keputusan bagi investor. Proses audit yang telah dilakukan dengan baik dapat meningkatkan kredibilitas dari informasi laporan keuangan, sehingga mendukung praktik tata kelola perusahaan yang lebih baik melalui adanya transparansi pelaporan keuangan.

Dalam teori agensi menyatakan bahwa perusahaan merupakan sekumpulan dari kontrak (nexus of contract) antara agent sebagai pengelola sumber daya dan principal sebagai pemilik sumber daya yang akan dikelola (Jensen \& Meckling, 1976). Hal tersebut menimbulkan dua permasalahan yaitu: adanya asimetri informasi (information asymmetry), yaitu sebuah kondisi di mana pihak manajemen memiliki informasi lebih banyak mengenai kondisi operasional serta kondisi keuangan perusahaan; dan (2) terjadi konflik kepentingan (conflict of interest) akibat tujuan yang berbeda yang mengakibatkan manajemen melakukan tindakan yang tidak sesuai dengan kepentingan pemilik . Komite Audit adalah salah satu fungsi pengawas yang penting dalam perusahaan. Peran penting yang dimiliki oleh komite adalah memastikan relevansi serta reliabilitas laporan keuangan perusahaan termasuk pengendalian internal (Widyaswari \& Suardana, 2014). Komite audit yang bekerja secara efektif dapat membantu dewan komisaris dalam meningkatkan kredibilitas laporan keuangan (Committees, 1999). Dengan adanya komite audit yang efektif akan meminimalisir asimetri informasi pada laporan keuangan perusahaan.

DeZoort et. al. (2002) mengungkapkan bahwa efektivitas komite audit ditentukan dari dua hal, yaitu sisi input yang berupa komposisi kualifikasi, kewenangan serta jumlah sumber daya, serta sisi proses yaitu harus memiliki etos kerja yang tinggi. Sehingga dari input dan proses komite audit diharapkan dapat bekerja dengan efektif dan mampu menghasilkan output yang berupa laporan. Semakin banyak jumlah komite audit akan menciptakan keberagaman pandangan, keahlian, pengalaman serta keterampilan untuk memastikan pengawasan yang efektif, sehingga lebih tinggi kemungkinan untuk mengungkapkan dan menyelesaikan masalah dalam proses pelaporan keuangan perusahaan (Setiany et. al., 2017). Komite audit juga melakukan rapat rutin sebanyak dua sampai tiga kali (FCGI, 2002) yang diharapkan dapat memenuhi tugas dan tanggung jawab komite audit dalam mengamati proses pelaporan keuangan dan memperbaiki kualitas pelaporan keuangan. Ayemere \& Elijah (2015) menyatakan bahwa keberadaan financial expert dalam komite audit d a pat membantu anggota komite audit untuk lebih fasih dengan laporan keuangan dan operasional yang memungkinkan mereka untuk melaksanakan tugas pengawasan mereka secara efektif. Komite audit yang independen juga akan lebih efektif dalam mengawasi manajemen perusahaan dikarenakan tidak memiliki hubungan dengan manajemen sehingga bisa mengurangi asimetri informasi antara agent dan principle (Armstrong et. al., 2014).

Penelitian yang dilakukan oleh (Chen \& Jaggi, 2000) mengemukakan bahwa keberadaan komite audit yang independen memiliki pengaruh signifikan terhadap pengungkapan sukarela laporan keuangan. Hal yang sama juga 
ditemukan Agyei-Mensah (2019) oleh dalam penelitiannya menguji hubungan antara keberadaan komite audit dengan pengungkapan sukarela perusahaan, hasil yang ditemukan bahwa komite audit memiliki pengaruh yang signifikan terhadap pengungkapan sukarela perusahaan.

$\mathrm{H}_{1}$ : Efektivitas komite audit berpengaruh positif terhadap pengungkapan sukarela perusahaan.

Internal audit sebagai salah satu dari pilar dari tata kelola perusahaan juga memiliki fungsi pengawasan internal yang efektif (Gramling et. al., 2004). Fungsi tersebut berkembang dalam struktur tata kelola yang memiliki suatu peran penting dalam menilai efektivitas pengendalian internal. Fungsi tersebut semakin dinilai penting karena internal audit melakukan pemeriksaan untuk memberikan jaminan bahwa pengendalian perusahaan sudah dilakukan dengan baik (Utami et. al., 2019), sehingga dapat berpengaruh untuk meningkatkan transparansi dan kualitas laporan keuangan. Sebagai contoh, SOX (2002) di Amerika Serikat mensyaratkan bahwa manajemen harus melaporkan efektivitas struktur kontrol internal dan pada tahun 2004 Bursa Efek New York mulai mengharuskan semua perusahaan yang terdaftar untuk memiliki internal audit.

Internal audit membantu perusahaan untuk mencapai tujuannya melalui pendekatan yang sistematis dan teratur untuk mengevaluasi dan meningkatkan efektivitas risiko, kontrol, dan proses tata kelola organisasi (Kewo \& Afiah, 2017). Internal audit dinilai dapat meningkatkan kontrol internal yang akan tercermin dalam peningkatan kualitas laporan keuangan perusahaan dalam hal mengurangi kesalahan pelaporan. Selain itu internal audit dapat meningkatkan kepercayaan investor dalam pengawasan perusahaan serta efektivitas dan keandalan pelaporan keuangan (Holt \& DeZoort, 2009). Hal tersebut didukung dengan ukuran dari auditor internal dan kompetensi dari anggota internal aud it cenderung meningkatkan kualitas fungsi intenral audit (Anderson et. al., 2012; Mat Zain et. al., 2015). Sehingga dengan adanya internal audit yang efekt if akan mengurangi asimetri informasi dalam perusahaan serta memperluas pengungkapan sukarela laporan keuangan.

Penelitian yang dilakukan oleh Mat Zain et.al. (2015) meneliti hubungan antara karakteristik komite audit, karakteristik fungsi internal audit dan penilaian auditor internal terhadap kontribusi mereka terhadap audit laporan keuangan. Menggunakan data survei dari kepala internal audit dari 76 perusahaan publik Malaysia. Hasil penelitian ini menemukan bahwa kualitas internal audit melalui ukuran intenral audit dan kompetensi anggota internal audit berkaitan dengan kontribusi auditor internal terhadap audit laporan keuangan.

$\mathrm{H}_{2}$ : Efektivitas internal audit berpengaruh positif terhadap pengungkapan sukarela perusahaan.

Auditing adalah bentuk monitoring yang digunakan untuk menurunkan biaya keagenan perusahaan dengan pemegang hutang dan pemegang saham (Jensen \& Meckling, 1976). Audit atas laporan keuangan dengan tingkat kualitas yang lebih baik akan meningkatkan sistem pengendalian yang baik, transparansi menjadi lebih tinggi sehingga dapat menaikkan kepercayaan investor kepada perusahaan. Audit yang berkualitas merupakan hal penting karena apabila kualitas audit dari suatu perusahaan tinggi maka akan menghasilkan laporan 
keuangan yang dapat dipercaya sebagai dasar pengambilan keputusan bagi investor (Muliawan \& Sujana, 2017).

Dopuch \& Simunic (1980) mengemukakan bahwa reputasi kantor akuntan publik menjadi salah satu penentu kualitas audit. Kantor akuntan publik yang memiliki reputasi baik akan lebih cenderung melakukan prosedur audit yang terstandarisasi dan jelas untuk menjaga nama baiknya. Per usahaan yang diaudit oleh kantor akuntan publik beruuran besar diharapkan dapat mengungkapkan informasi keuangan dengan lebih luas karena kantor akuntan publik tersebut memiliki insentif untuk melindungi reputasinya sehingga dapat lebih transparan dan mendorong luasnya pengungkapan di laporan keuangan (Comprix \& Huang, 2015), (DeAngelo, 1981), dan (Dehkordi \& Makarem, 2011).

Hasil penelitian DeAngelo (1981) menemukan bahwa terdapat hubungan antara kualitas audit dan ukuran kantor akuntan publik, yang didukung oleh penelitian Francis (1984) dan Lennox \& Pittman (2010). Hal yang sama juga ditemukan dalam penelitian yang dilakukan oleh Ball et. al. (2012) menguji laporan keuangan yang diaudit dengan pengungkapan sukarela perusahaan. Peneliti menggunakan sampel sebanyak 44.883 mencakup periode 2000 hingga 2007. Adapun hasilnya ditemukan bahwa perusahaan yang melakukan verifikasi laporan keuangan oleh auditor independen akan meningkatkan aktivitas pelaporan sukarela perusahaan.

$\mathrm{H}_{3}$ : Kualitas audit berpengaruh positif terhadap pengungkapan sukarela perusahaan.

Penelitan ini melanjutkan penelitian sebelumnya dengan menggabungkan fungsi dari pengawasan. Penelitian ini berkonteks pada kebutuhan akan transparansi dan fairness yang merupakan sebuah tanggung jawab manajemen kepada pemilik perusahaan, sehingga menjadi penting untuk meningkatkan kualitas pelaporan keuangan dengan cara meningkatkan pengungkapan sukarela yang lebih luas. Dalam penelitian ini berfokus pada aspek audit berserta organ-organ yang terkait dengan audit baik dari internal maupun eksternal perusahaan untuk dapat mendorong dan menciptakan pengungkapan sukarela perusahaan secara lebih luas.

\section{METODE PENELITIAN}

Penelitian ini merupakan penelitian kuantitatif dengan pendekatan eksplanatori, desain penelitian yang digunakan akan digambarkan pada Gambar 1. sebagai berikut :

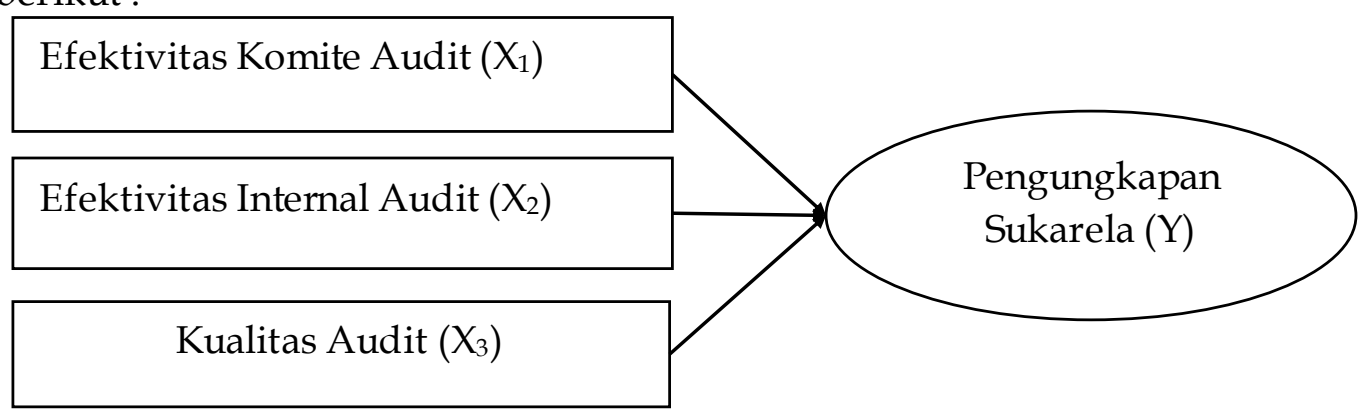

\section{Gambar 1. Model Penelitian}

Sumber: Data Penelitian, 2019 
Penelitian ini menggunakan data laporan keuangan (financial report) dan laporan tahunan (annual report) perusahaan sesuai kriteria sampel yang didapatkan dari situs Bursa Efek Indonesia (www.idx.co.id). Populasi dalam penelitian ini adalah perusahaan sektor manufaktur yang terdaftar di Bursa Efek Indonesia periode tahun 2016 hingga tahun 2018 yang meliputi sektor industri dasar dan kimia, sektor aneka industri dan sektor industri barang konsumsi. Teknik penarikan sampel yang digunakan dalam penelitian ini adalah metode purposive sampling, dengan pertimbangan yang ditentukan oleh peneliti antara lain : Perusahaan sektor manufaktur yang terdaftar dan terpublikasi pada Bursa Efek Indonesia dari tahun 2016-2018; Periode akuntansi perusahaan berakhir pada tanggal 31 Desember; Laporan tahunan perusahaan menyajikan data yang dibutuhkan oleh peneliti, sehingga data perusahaan yang digunakan dalam penelitian ini sejumlah 100 perusahaan sektor manufaktur periode tahun 20162018

Variabel-variabel yang diuji dalam penelitian ini antara lain: variabel dependen berupa Pengungkapan Sukarela (Y), variabel independennya meliputi Efektivitas Komite Audit $\left(X_{1}\right)$, Efektivitas Internal Audit $\left(X_{2}\right)$ dan Kualitas Audit $\left(X_{3}\right)$. Pengungkapan sukarela merupakan merupakan jenis informasi keuangan yang disajikan kepada publik secara sukarela dalam laporan keuangan perusahaan, tanpa adanya kewajiban untuk menyampaikannya. Variabel pengungkapan sukarela diukur dengan menggunakan checklist oleh Meek et. al. (1995) dengan penyesuaian peraturan BAPEPAM-LK. Jumlah kriteria awal dalam Meek et.al. (1995) adalah 85 item, setelah disesuaikan dengan Pedoman Penyajian Laporan Keuangan dalam Peraturan Otoritas Jasa Keuangan No: KEP347/BL/2012, terdapat 17 list yang sudah terkategorikan wajib di Indonesia, sehingga totap checklist yang dipakai dalam penelitian ini adalah 68. Setiap item pengungkapan sukarela akan diukur dengan konten analisis, akan bernilai 1 jika item informasi sesuai dengan metode pengungkapan sukarela yang ditentukan dan diberi nilai 0 jika item pengungkapan informasi tidak sesuai.

Skor Pengungkapan Sukarela $=\frac{\sum \text { Pengungkapan Sukarela Perusahaan }}{\sum \text { Pengungkapan Sukarela yang diharapkan }}$.

Efektivitas komite audit merupakan kemampuan komite audit dalam melaksanakan tugas dan tanggung jawab pengawasannya. Efektivitas komite audit akan diukur dengan menggunakan skor komposit gabungan, di mana setiap elemen memiliki nilai dummy 0 atau 1 . Elemen akan bernilai 1 apabila di atas nilai median sampel dan bernilai 0 apabila di bawah nilai median sampel. Skor komposit efektivitas komite audit akan bernilai antara 0 dan 1, nilai 0 menunjukkan efektivitas terendah dan 4 efektivitas tertinggi (Idris et. al., 2018). Skor tersebut dibentuk dengan menggabungkan empat karakteristik yang dimiliki komite audit, antara lain: Jumlah anggota komite audit, Frekuensi rapat, Independensi dan Keahlian keuangan.

Efektivitas internal audit merupakan kemampuan dalam melaksanakan tugas dan tanggung jawabnya terhadap kualitas pelaporan keuangan. Variabel Efektivitas internal audit akan diukur dengan menggunakan skor komposit gabungan, di mana setiap elemen memiliki nilai dummy 0 atau 1. Elemen akan 
bernilai 1 apabila di atas nilai median sampel dan bernilai 0 apabila di bawah nilai median sampel. Skor komposit efektivitas internal audit akan bernilai antara 0 dan 1, nilai 0 menunjukkan efektivitas terendah dan 2 efektivitas tertinggi (Idris et.al., 2018). Skor tersebut dibentuk dengan menggabungkan dua karakteristik yang dimiliki internal audit, yaitu: Jumlah anggota internal audit dan Keahlian keuangan kepala internal audit.

Kualitas aduit merupakan karakteristik audit yang memenuhi standard auditing serta standar penendalian mutu. Kualitas audit akan diukur dengan menggunakan variabel dummy, apabila perusahaan diaudit oleh KAP big 4 akan diberi skor 1, sedangkan apabila perusahaan diaudit oleh selain KAP big akan diberi skor 0. Adapun KAP yang termasuk big 4 di Indonesia antara lain: KAP Deloitte, KAP PriceWaterhouseCoopers, KAP Ernst and Young dan KAP KPMG.

Berdasarkan kriteria penarikan sampel maka diperoleh jumlah perusahaan yang memenuhi kriteria penentuan penentuan sampel untuk penelitian ini sebanyak 100 perusahaan selama tiga tahun dari tahun 2016 sampai 2018. Metode pengumpulan data yang digunakan dalam penelitian ini adalah dokumentasi. Adapun teknik analisis data yang digunakan dalam penelitian ini antara lain: Uji Statistik Deskriptif, Uji Asumsi Klasik, Uji Regresi Linier Berganda dan Uji Hipotesis dengan persamaan model seperti berikut: $\mathrm{VD}_{\mathrm{it}}=\alpha+\beta_{1} \mathrm{ACE}_{\mathrm{it}}+\beta_{2} \mathrm{IAE}_{\mathrm{it}}+\beta_{3} \mathrm{AQ}_{\mathrm{it}}+\beta_{4} \mathrm{FSIZE}_{\mathrm{it}}+\beta_{5} \mathrm{LEV}_{\mathrm{it}}+\beta_{6} \mathrm{ROE}_{\mathrm{it}}+$ eit ........(2) Keterangan: aKonstanta

$\mathrm{VD}_{\text {it }}$

$\mathrm{ACE}_{\mathrm{it}}$

$\mathrm{IAE}_{\mathrm{it}}$

$\mathrm{AQ}_{\mathrm{it}}$

FSIZE $_{\text {it }}$

$\mathrm{LEV}_{\text {it }}$

$\mathrm{ROE}_{\mathrm{it}}$
: Pengungkapan Sukarela perusahaan $i$ tahun $t$

: Efektivitas Komite Audit perusahaan $i$ tahun $t$

: Efektivitas Internal Audit perusahaan $i$ tahun $t$

: Kualitas Audit perusahaan $i$ tahun $t$

: Ukuran Perusahaan $i$ tahun $t$

: Nilai Hutang perusahaan $i$ tahun $t$

: Net Profit dibagi total Shareholder's Equity perusahaan $i$ tahun $t$

\section{HASIL DAN PEMBAHASAN}

Penelitian ini menggunakan objek perusahaan manufaktur yang terdaftar di Bursa Efek Indoensia periode tahun 2016-2018. Penelitian ini menggunakan metode purposive sampling yaitu teknik penentuan sampel dengan pertimbangan tertentu di mana anggota sampel dapat mewakili sifat-sifat populasi, sehingga data perusahaan yang digunakan dalam penelitian ini sejumlah 100 perusaha an sektor manufaktur periode tahun 2016-2018.

Berdasarkan hasil yang terdapat pada tabel 1 dapat diketahu bahwa pengungkapan sukarela perusahaan (VCD) memiliki nilai minimum sebesar 0,24 yaitu KMI Wire\&Cable Tbk, Gunawan Dianjaya Steel Tbk pada periode 2017 dan Garuda Maintenance Tbk pada periode 2017. Nilai maksimum sebesar 0,45 pada Darya Varia Laboratoria Tbk di periode 2017. Pengungkapan sukarela perusahaan memiliki rata-rata sebesar 0,3154 dan standar deviasi sebesar 0,0393. 
Tabel 1. Statistik Deskriptif Variabel Penelitian

\begin{tabular}{lcllll}
\hline & $\mathrm{N}$ & Minimum & Maximum & Mean & Std. Deviation \\
\hline VCD & 100 & 0,24 & 0,45 & 0,3154 & 0,0393 \\
AC & 100 & 0,00 & 0,75 & 0,2257 & 0,18821 \\
IA & 100 & 0,00 & 1,00 & 0,6100 & 0,34510 \\
AQ & 100 & 0,00 & 1,00 & 0,5000 & 0,50252 \\
SIZE & 100 & 20,43 & 33,32 & 28,9432 & 1,74158 \\
LEV & 100 & 0,00 & 11,10 & 1,1140 & 1.51258 \\
ROE & 100 & $-0,45$ & 4,67 & 0,1675 & 0,52230 \\
Valid N (listwise) & 100 & & & & \\
\hline
\end{tabular}

Sumber: Data Penelitian, 2019

$\mathrm{X}_{1}$ memiliki nilai sebesar $\min 0,00$ dan nilai max sebesar 0,75 mean ataurata-rata sebesar 0,2257 dan standar deviasi sebesar 0,18821. $X_{2}$ memiliki nilai max sebesar 1,00 dan nilai min sebesar 0,00 mean atau rata-rata sebesar 0,6100 dan standar deviasi sebesar $0,34510 . X_{3}$ memiliki nilai sebesar min 0,00 dan nilai max sebesar 1,00 mean atau rata-rata sebesar 0,5000 dan standar deviasi sebesar 0,50252 .

Tabel 2. Hasil Analisis Regresi Linier Berganda

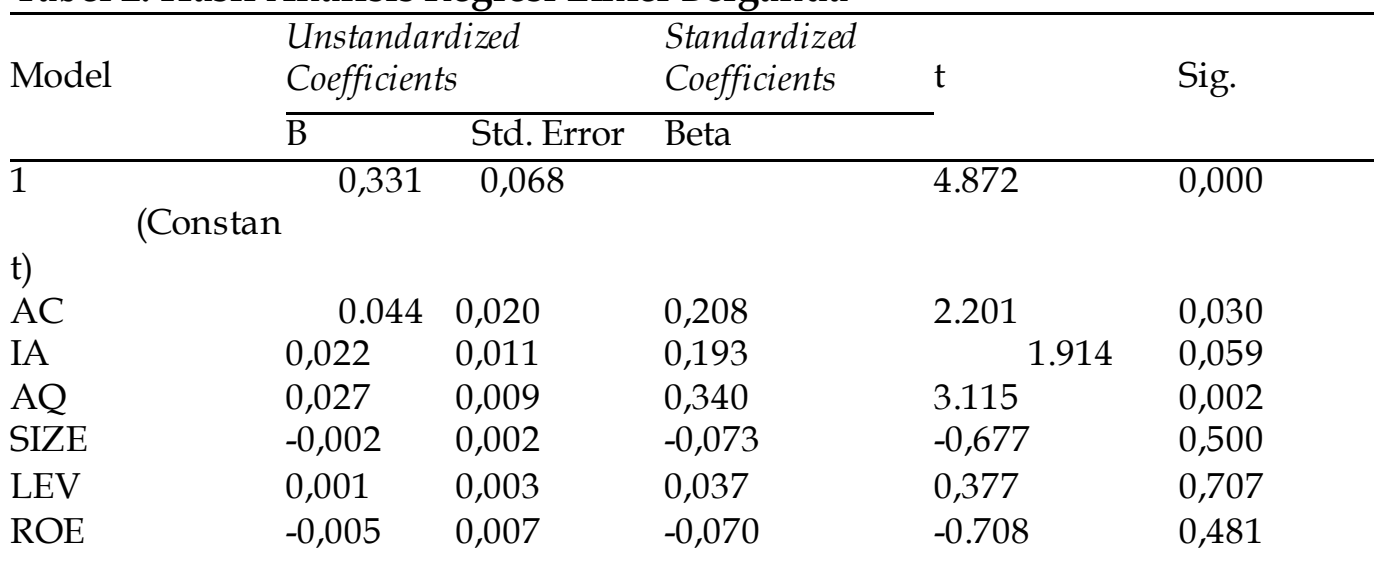

Sumber: Data Penelitian, 2019

Berdasarkan hasil analisis pada Tabel 2. maka persamaan regresi yang digunakan dalam penelitian ini dapat ditulis sebagai berikut:

$$
Y=0,331+0,044 X_{1}+0,022 X_{2}+0,027 X_{3}+e
$$

Keterangan :

$\mathrm{Y}=$ Pengungkapan Sukarela Perusahaan

$\mathrm{X}_{1}=$ Efektifitas Komite Audit

$\mathrm{X}_{2}=$ Efektifitas Internal Audit

$\mathrm{X}_{3}=$ Kualitas Audit

Berdasarkan persamaan tersebut, dapat dijelaskan beberapa hal-hal sebagai berikut. Nilai konstanta 0,331 menunjukkan bahwa apabila pengungkapan $X_{1}, X_{2}$ dan $X_{3}$ sama dengan nol, maka pengungkapan sukarela perusahaan (Y) tidak ada. Nilai Koefisien $\mathrm{X}_{1}=0,044$ menunjukkan bahwa jika efektifitas komite audit $\left(\mathrm{X}_{2}\right)$ bertambah 1 satuan, maka pengungkapan sukarela perusahaan $(\mathrm{Y})$ berubah sebesar 0,044 satuan dengan asumsi variabel lainnya konstan. Nilai Koefisien $\mathrm{X}_{2}=0,022$ menunjukkan bahwa jika efektifitas internal 
audit $\left(\mathrm{X}_{2}\right)$ bertambah 1 satuan, maka pengungkapan sukarela perusahaan $(\mathrm{Y})$ akan berubah sebesar 0,022 satuan dengan asumsi variabel lainnya konstan. Nilai Koefisien $X_{3}=0,027$ menunjukkan bahwa jika kualitas audit $\left(X_{3}\right)$ bertambah 1 satuan, maka pengungkapan sukarela perusahaan (Y) akan berubah sebesar 0,027 satuan dengan asumsi variabel lainnya konstan.

Tabel 3. Hasil Uji Statistik F (Uji F) - hapus

\begin{tabular}{llllll}
\hline Model & $\begin{array}{l}\text { Sum of } \\
\text { Squares }\end{array}$ & $d f$ & $\begin{array}{l}\text { Mean } \\
\text { S quare }\end{array}$ & F & Sig. \\
\hline 1Regression Residual & 0,026 & 6 & 0,004 & 3.178 & $0,007 \mathrm{~b}$ \\
Total & 0,127 & 93 & 0,001 & & \\
& 0,153 & 99 & & &
\end{tabular}

Sumber: Data Penelitian, 2019

Berdasarkan Tabel 3. nilai signifikansi F adalah sebesar 0,007 lebih kecil dari $a=0,1$ yang berarti variabel independen berpengaruh signifikan secara serempak atau bersama-sama terhadap variabel dependen, sehingga model layak diteliti.

Tabel 4. Hasil Koefisien Determinasi (R2)

\begin{tabular}{lcccc}
\hline Model & $\mathrm{R}$ & RSquare & $\begin{array}{l}\text { Adjusted R } \\
\text { Square }\end{array}$ & $\begin{array}{l}\text { Std. Error of the } \\
\text { Estimate }\end{array}$ \\
\hline 1 & $0,412 \mathrm{a}$ & 0,170 & 0,117 & 0,03694 \\
\hline
\end{tabular}

Sumber : Data Penelitian, 2019

$\mathrm{R}^{2}$ memiliki nilai sebesar 0,117 memiliki arti bahwa 11,7 persen variasi dari variabel dependen, yaitu pengungkapan sukarela perusahaan (Y) dapat dijelaskan oleh variasi dari variabel independen antara lain: ef ektivitas komite audit, efektivitas internal audit dan kualitas audit.

Hasil yang didapatkan dari pengolahan data yang dilakukan adalah $\mathrm{H} 1$ diterima. Pada hipotesis satu dinyatakan bahwa efektivitas komite audit berpengaruh positif terhadap pengungkapan sukarela perusahaan. Setelah dilakukan pengolahan data didapatkan nilai sig. dari AC atau $\mathrm{X}_{1}$ adalah sebesar 0,030 . Dengan nilai 0,030 dimana lebih kecil dari 0,1 hal ini berarti ditemukan pengaruh signifikan positif dari $\mathrm{X}_{1}$ pada $\mathrm{Y}$ atau pengungkapan sukarela perusahaan.

Hasil penelitian sejalan dengan penelitian Akhtaruddin \& Haron (2010) dan Agyei Mensah (2019). Konflik agensi yang terjadi dalam perusahaan dapat diatasi dengan efektifnya komite audit. Melalui fungsi pemantauan yang intensif akan meningkatkan pengungkapan sukarela informasi yang lebih luas (Samaha et. al., 2015). Dengan adanya efektivitas komite audit akan mendorong manajemen untuk melakukan pengungkapan sukarela yang lebih luas, sehingga masalah agensi tersebut dapat diminimalisir. Sebagai salah satu fungsi pengawasan dalam perusahaan, komite audit memegang penting dalam memantau pelaporan keuangan termasuk pengendalian internal. Anggota komite audit secara konsisten melakukan evaluasi pengendalian internal sebagai aspek pengawasan yang paling penting. Melalui pegawasan pengendalian internal akan memastikan bahwa pihak manajemen melakukan pelaporan informasi keuangan perusahaan sesuai. Diharapkan melalui fungsi pengawasannya, komite audit dapat mendorong atau memberi saran kepada manajemen untuk menghasilkan informasi keuangan yang tepat melalui 
pengungkapan yang memadai (Song \& Windram, 2004) serta mendorong manajemen untuk melakukan pengungkapan yang lebih luas.

Hasil yang didapatkan dari pengolahan data yang dilakukan adalah $\mathrm{H} 2$ diterima. Pada hipotesis satu dinyatakan bahwa efektivitas internal audit berpengaruh positif terhadap pengungkapan sukarela perusahaan. Setelah dilakukan pengolahan data didapatkan nilai sig. dari AC atau $X_{1}$ adalah sebesar 0,059. Dengan nilai 0,59 dimana lebih kecil dari 0,1 hal ini berarti ditemukan pengaruh signifikan positif dari $\mathrm{X}_{2}$ pada $\mathrm{Y}$ atau pengungkapan sukarela perusahaan.

Hasil peneltian sesuai dengan teori agensi yang menyatakan bahwa agent memiliki lebih banyak informasi dibandingkan principal dan bahwa informasi asimetri ini akan berdampak buruk pada kemampuan principal untuk memantau apakah kepentingan mereka diwujudkan oleh agent (Jensen \& Meckling, 1976). Untuk mengatasi informasi asimetri tersebut, maka diperlukan peran internal audit yang efektif dalam melakukan kontrol atas pengelolaan perusahaan. Kontrol yang dilakukan oleh internal auditor tersebut mendorong manajemen perusahaan untuk lebih luas dalam melakukan pengungkapan laporan keuangan. Internal audit melakukan analisis dan penilaian independen terhadap kecukupan dan efektivitas manajemen risiko perusahaan dan kontrol internal, sehingga dinilai mampu untuk mencegah penyimpangan pelaporan keuangan. Sehingga dengan adanya internal audit yang efektif akan mengurangi asimetri informasi dalam perusahaan serta memperluas pengungkapan sukarela laporan keuangan.

Hasil yang didapatkan dari pengolahan data yang dilakukan ad alah $\mathrm{H} 3$ diterima. Pada hipotesis satu dinyatakan bahwa kualitas audit berpengaruh positif terhadap pengungkapan sukarela perusahaan. Setelah dilakukan pengolahan data didapatkan nilai sig. dari AC atau $\mathrm{X}_{1}$ adalah sebesar 0,002. Dengan nilai 0,002 dimana lebih kecil dari 0,1 hal ini berarti ditemukan pengaruh signifikan positif dari $\mathrm{X}_{3}$ pada $\mathrm{Y}$ atau pengungkapan sukarela perusahaan.

Hasil penelitian sejalan dengan Ball et. al., (2012) dan Ahmadi \& Bouri (2017). Seperti yang diperkirakan, KAP Big 4 mengambil inisiatif untuk mengurangi informasi asimetri antara manajer dan para stakeholder serta akan meningkatkan transparansi informasi yang diungkapkan. Dengan kata lain, keberadaan KAP Big 4 secara positif terkait dengan tingkat praktik pengungkapan perusahaan dari perusahaan-perusahaan yang terd aftar di BEI. Demikian juga, perusahaan yang diaudit oleh KAP Big 4 berkontribusi untuk meningkatkan kualitas dan tingkat informasi pengungkapan sukarela melalui dalam laporan tahunan perusahaan-perusahaan. Sehingga, perusahaan yang diaudit oleh KAP Big 4 diharapkan untuk mengungkapkan secara publik tingkat informasi keuangan dan akuntansi yang lebih tinggi.

\section{SIMPULAN}

Penelitian ini dilakukan untuk menguji komponen-kompen audit yang dapat mempengaruhi pengungkapan sukarela perusahaan yang dilihat dari Efektivitas Komite Audit, Efektivitas Internal Audit dan Kualitas Audit pada perusahaan manufaktur yang terdaftar di Bursa Efek Indonesia periode 2016-2018. Simpulan dari penelitian ini adalah bahwa Efektivitas Komite Audit, Efektivitas Internal 
Audit dan Internal Audit berpengaruh positif pada Pengungkapan Sukarela perusahaan.

Adapun keterbatasan dalam penelitian ini hanya menggunakan sampel perusahaan manufaktur yang terbatas hanya pada tahun 2016-2018. Penelitian selanjutnya disaranakan untuk menggunakan sampel dengan rentang waktu pengamatan yang lebih panjang, serta menggunakan proksi lain terkait dengan pengukuran dari kualitas audit. Bagi perusahaan, penelitian ini diharapkan memberikan masukan dan tambahan informasi mengenai pentingnya mekanisme pemantauan internal dan eksternal terhadap pengungkapan sukarela perusahaan, sehingga perusahaan dapat meningkatkan kualitas pengungkapan sukarela dalam laporan keuangannya yang dibutuhkan oleh investor dan para pengguna laporan keuangan lainnya.

\section{REFERENSI}

Agyei Mensah, B. K. (2019). The effect of audit committee effectiveness and audit quality on corporate voluntary disclosure quality. African Journal of Economic and Management Studies, 10(1), 17-31.

Akhtaruddin, M., \& Haron, H. (2010). Board ownership, audit committees' effectiveness and corporate voluntary disclosures. Journal Asian Review of Accounting, 18(1), 68-82.

Anderson, U. L., Christ, M. H., Johnstone, K. M., \& Rittenberg, L. E. (2012). A post-SOX examination of factors associated with the size of internal audit functions. Accounting Horizons, 26(2), 167-191.

Armstrong, C. S., Core, J. E., \& Guay, W. R. (2014). Do independent directors cause improvements in firm transparency? Journal of financial Economics, 113(3), 383-403.

Ayemere, I. L., \& Elijah, A. (2015). Audit committee attributes and earnings management: Evidence from Nigeria. International Journal of Business and Social Research, 5(4), 14-23.

Ball, R., Jayaraman, S., \& Shivakumar, L. (2012). Audited financial reporting and voluntary disclosure as complements: A test of the confirmation hypothesis. Journal of accounting and economics, 53(1-2), 136-166.

Berger, A. N., \& DeYoung, R. (1997). Problem Loans and Cost Efficiency in Commercial Banks. Journal of Banking \& Finance, 21(6), 849-870.

Chen, C. J., \& Jaggi, B. (2000). Association between independent non-executive directors, family control and financial disclosures in Hong Kong. Journal of Accounting and public Policy, 19(4-5), 285-310.

Committees, B. R. C. o. I. t. E. o. C. A. (1999). Report and recommendations of the Blue Ribbon Committee on improving the effectiveness of corporate audit committees. The Business Lawyer, 1067-1095.

Comprix, J., \& Huang, H. (2015). Does auditor size matter? Evidence from small audit firms. Advances in accounting, 31(1),11-20.

DeAngelo, L. E. (1981). Auditor size and audit quality. Journal of accounting and economics, 3(3), 183-199.

Dehkordi, H.F., \& Makarem, N. (2011). The effect of size and type of auditor on audit quality. International research journal of finance and economics(80), 121. 
DeZoort, F. T., Hermanson, D. R., Archambeault, D. S., \& Reed, S. A. (2002). Audit committee effectiveness: A synthesis of the empirical audit committee literature. Audit Committee Effectiveness: A Synthesis of the Empirical Audit Committee Literature, 21, 38.

Dopuch, N., \& Simunic, D. (1980). The nature of competition in the auditing profession: a descriptive and normative view in Regulation and the Accounting Profession, J Buckley and F Weston eds. In: Learning Publications.

Francis, J. R. (1984). The effect of audit firm size on audit prices: A study of the Australian market. Journal of accounting and economics, 6(2), 133-151.

Gramling, A. A., Maletta, M. J., Schneider, A., \& Church, B. K. (2004). The role of the internal audit function in corporate governance: A synthesis of the extant internal auditing literature and directions for future research. Journal of Accounting literature, 23, 194.

Holt, T. P., \& DeZoort, T. (2009). The effects of internal audit report disclosure on investor confidence and investment decisions. International journal of auditing, 13(1), 61-77.

Idris, M. I., Siam, Y. I. A., \& Ahmad, A. L. (2018). The impact of external auditor size on the relationship between audit committee effectiveness and earnings management. Investment Management $\mathcal{E}$ Financial Innovations, 15(3), 122.

Jensen, M. C., \& Meckling, W. H. (1976). Theory of the firm: Managerial behavior, agency costs and ownership structure. Journal of financial economics, 3(4), 305-360.

Kamolsakulchai, M. (2015). The impact of the audit committee effectiveness and audit quality on financial reporting quality of listed company in stocks exchange of Thailand. Review of Integrative Business and Economics Research, 4(2), 328.

Kewo, C. L., \& Afiah, N. N. (2017). Does Quality of Financial Statement Affected by Internal Control System and Internal Audit? International Journal of Economics and Financial Issues, 7(2), 568-573.

Kieso, D. E., Weygandt, J. J., \& Warfield, T. D. (2019). Intermediate accounting: John Wiley \& Sons.

Lennox, C., \& Pittman, J. (2010). Auditing the auditors: Evid ence on the recent reforms to the external monitoring of audit firms. Journal of accounting and economics, 49(1-2), 84-103.

Mat Zain, M., Zaman, M., \& Mohamed, Z. (2015). The effect of internal audit function quality and internal audit contribution to external audit on audit fees. International journal of auditing, 19(3), 134-147.

Meek, G. K., Roberts, C. B., \& Gray, S. J. (1995). Factors influencing voluntary annual report disclosures by US, UK and continental European multinational corporations. Journal of international business studies, 26(3), 555-572.

Muliawan, E. K., \& Sujana, I. K. (2017). Pengaruh Ukuran Kantor Akuntan Publik, Auditor Switching dan Audit Tenure Pada Kualitas Audit. EJurnal Akuntansi Universitas Udayana, 21(1), 534-561. 
Salierno, D. (2007). Managing change: FASB chairman Robert Herz says that meeting the demand for improved financial reporting standards is a matter of balance. Internal Auditor, 64(1), 51-55.

Samaha, K., Khlif, H., \& Hussainey, K. (2015). The impact of board and audit committee characteristics on voluntary disclosure: A meta-analysis. Journal of International Accounting, Auditing and Taxation, 24, 13-28.

Setiany, E., Hartoko, S., Suhardjanto, D., \& Honggowati, S. (2017). Audit committee characteristics and voluntary financial disclosure. Review of Integrative Business and Economics Research, 6(3), 239.

Song, J., \& Windram, B. (2004). Benchmarking audit committee effectiveness in financial reporting. International Journal of Auditing, 8(3), 195-205.

Ulf, \& Agi. (2019). Kronologi Kisruh Laporan Keuangan Garuda Indonesia. Retrieved

from https://www.cnnindonesia.com/ekonomi/20190430174733-92390927/kronologi-kisruh-laporan-keuangan-garuda-indonesia

Utami, L., Handajani, L., \& Hermanto, H. (2019). Efektivitas Komite Audit dan Audit Internal terhadap Kasus Kecurangan dengan Whistleblowing System sebagai Variabel Pemoderasi. E-Jurnal Akuntansi, 1570-1600.

Widyaswari, K. R., \& Suardana, K. A. (2014). Pengaruh Karakteristik Komite Audit terhadap Timeliness Pelaporan Keuangan: Perusahaan Go Public yang Terdaftar di Bursa Efek Indonesia. E-Jurnal Akuntansi, 154166.

Yassin, F. M., \& Nelson, S. P. (2012). Audit committee and internal audit: implications on audit quality. International Journal of Economics, Management and Accounting, 20(2). 